\title{
Impact of Saline Mine Water: Development of a Meromictic Reservoir in Poland
}

\author{
Tadeusz Molenda
}

Received: 15 September 2012/ Accepted: 5 March 2014/Published online: 26 March 2014

(C) The Author(s) 2014. This article is published with open access at Springerlink.com

\begin{abstract}
The hard coal mines in the Upper Silesian Coal Basin of southern Poland have highly saline waste water. In the past, such water was often discharged into nearby reservoirs, which would completely change the physicalchemical properties of the reservoir water. In some cases, it also caused permanent stratification; meromictic reservoirs were created. This paper describes the properties of the water in one such reservoir, in a mined out rock quarry in Katowice (southern Poland). Three zones characteristic of meromictic water bodies can be distinguished in the reservoir: a surface atmosphere responsive zone (mixolimnion), a transition zone (chemocline), and a bottom unmixed layer (monolimnion). For comparison, baseline conditions for normal reservoir water were assumed to be represented by the nearby Grunfeld reservoir, which also formed in a closed quarry, but was not used for disposal of mine waste water.
\end{abstract}

Keywords Hydrochemistry · Meromixis · Pit reservoir · Water pollution

\section{Introduction}

There are many hard coal mines in the Upper Silesian Coal Basin in southern Poland, and the water in these mines is typically highly saline (Różkowski 2004). In the past, this water was often discharged into manmade reservoirs near the mines, which completely changed the physical-chemical properties of the reservoir water. Although disposal of mine water into these reservoirs has been discontinued, the reservoirs are still highly saline and some are meromictic

T. Molenda $(\bowtie)$

University of Silesia, Będzińska 60, 41-200 Sosnowiec, Poland

e-mail: tedimolenda@interia.pl
(Molenda 2011). Meromixis, although unusual, is a phenomenon that exists in both natural and man-made lakes (Boehrer and Schultze 2008; Hutchinson 1957). It is often associated with closed pit lakes and with wastewater ponds of lignite (Dietz et al. 2012; Jędrczak 1992), sulphur (Frankiewicz and Pucek 2006; Wilk-Woźniak and Żurek 2005; Żurek 2002), and gypsum (Madonia et al. 2006) mines. Meromixis can also be caused by the inflow of highly saline mine waste water (Galas 2003; Molenda 2011; Motyka and Postawa 2000) or the inflow of leachate water from colliery waste tips (Czop et al. 2011; Molenda 2005). This paper describes the characteristics of one such meromictic water body in the Gliniok reservoir.

The Gliniok meromictic reservoir (coordinates: $50^{\circ} 14^{\prime}$ $25.55^{\prime \prime} \mathrm{N} ; 18^{\circ} 59^{\prime} 33.36^{\prime \prime} \mathrm{E}$ ) is situated in Katowice (Fig. 1). The nearby Grunfeld reservoir (coordinates: $50^{\circ} 14^{\prime} 25.34^{\prime \prime}$ $\mathrm{N} ; 19^{\circ} 1^{\prime} 16.25^{\prime \prime} \mathrm{E}$ ), which is not impacted by saline mine wastewater, was chosen to represent baseline pre-mining impact conditions (Fig. 1). Both of the reservoirs are formed in quarry voids left after the exploitation of Carboniferous sandstone and shale materials for the building industry. Hard coal layers cropped out in the quarry walls. The quarries flooded after the exploitation was finished and dewatering was discontinued. Water inflow to the reservoirs mostly consists of groundwater from a shallow sandstone aquifer horizon in the Carboniferous formation. Hydrologically, these are closed reservoirs, in that they do not have surface inflows or outflows. The surface area and capacity of the Gliniok reservoir are 1.7 ha and $25,860 \mathrm{~m}^{3}$, while that of the Grunfeld reservoir is 3.8 ha and $82,747 \mathrm{~m}^{3}$. The bathymetric plans of the reservoirs are depicted in Figs. 2 and 3; the maximum depth of the Grunfeld reservoir is more than $9 \mathrm{~m}$, while that of the Gliniok reservoir is $7 \mathrm{~m}$. 
Fig. 1 Localization of investigated reservoirs: 1 Wujek coal mine; 2 direction of mine waters discharge;

3 anthropogenic reservoirs;

4 roads
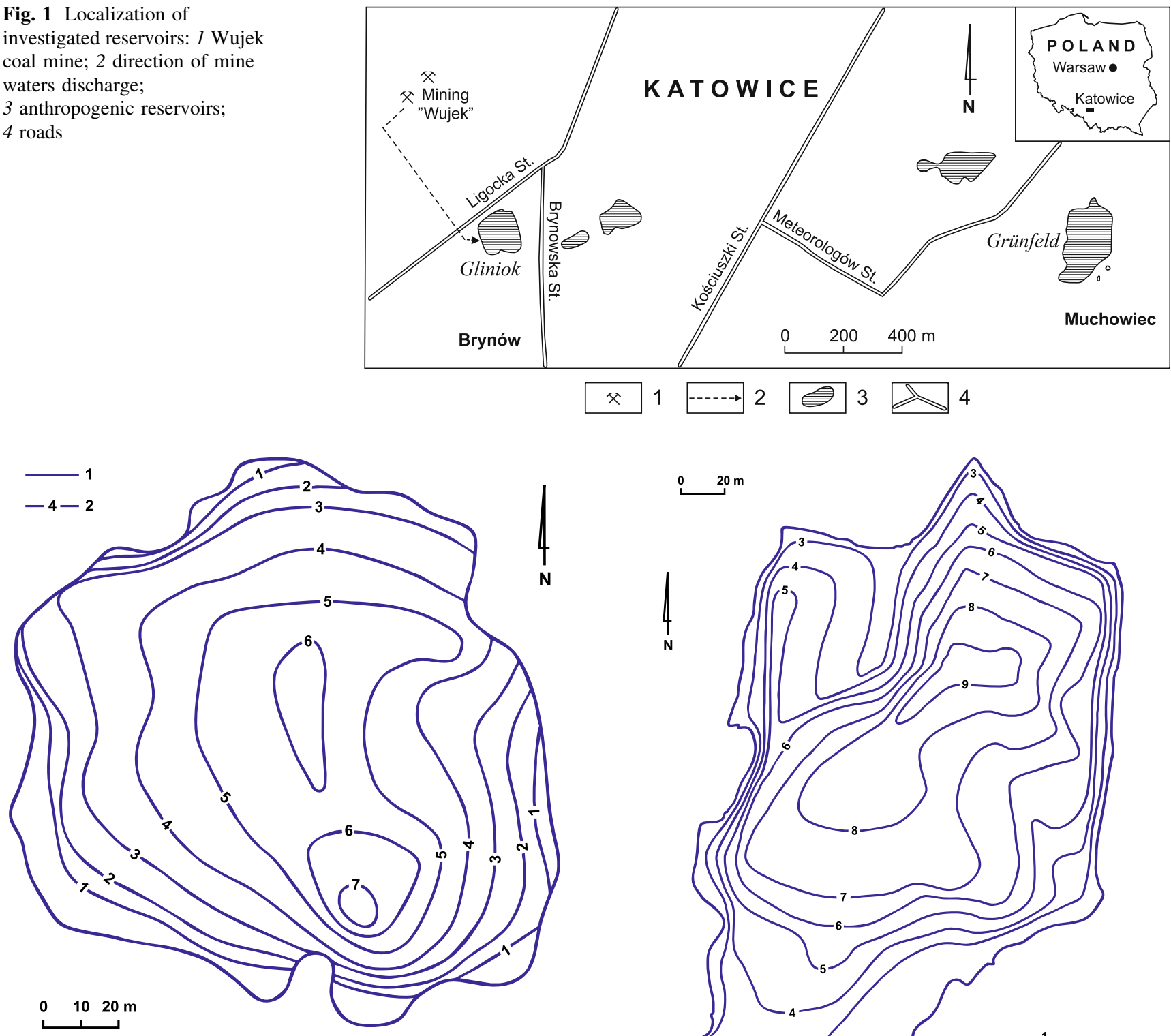

Fig. 2 Bathymetric map of the Gliniok reservoir: 1 bank; 2 isobars (m)

Initially, the chemical composition of the water in both reservoirs was similar, due to their equivalent geology and shared groundwater source. Archival data from the 1960s indicates that the water in the Gliniok reservoir was characterised by electrical conductivity (EC) $<500 \mathrm{uS} / \mathrm{cm}$. Moreover, studies by Molenda (2011) clearly indicate that all water bodies located in the workings in these Carboniferous rocks represent a bicarbonate-calcium type of water $\left(\mathrm{HCO}_{3}{ }^{-}-\mathrm{Ca}^{2+}\right)$ of $\mathrm{EC}<500 \mathrm{uS} / \mathrm{cm}$. In the $1970 \mathrm{~s}$, the Gliniok reservoir was adopted as a mine water settlement pond for the Wujek hard coal mine. The waste water discharged into the pond was brine with an average EC of 33 $\mathrm{mS} / \mathrm{cm}$; the average chloride content was $12,500 \mathrm{mg} / \mathrm{L}$. During mining, the reservoir was used as both a waste water disposal facility and as a water resource for use in

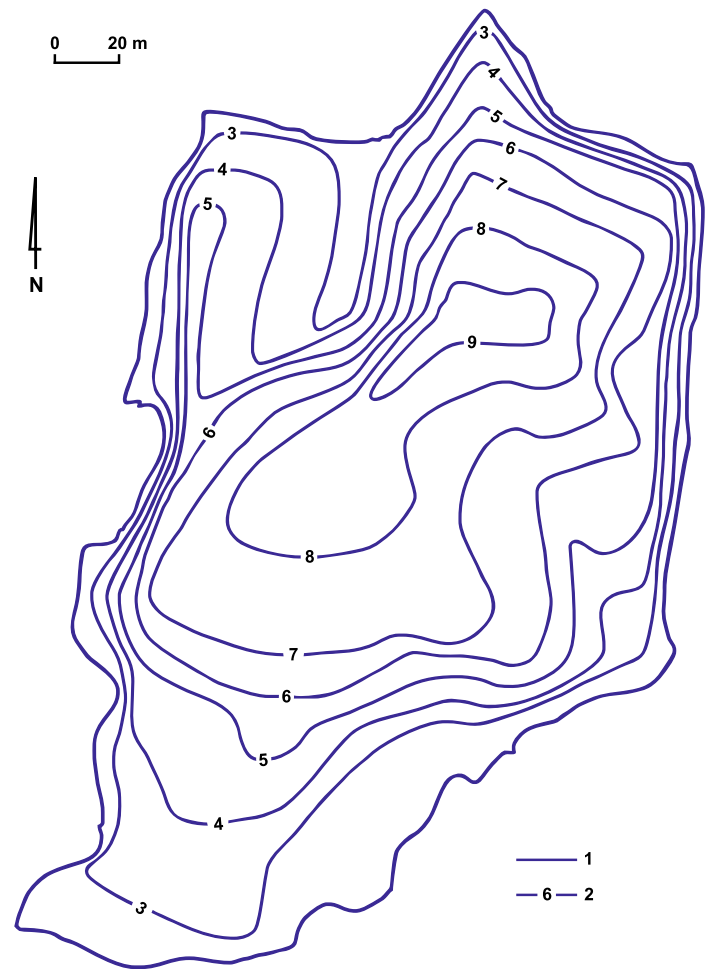

Fig. 3 Bathymetric map of the Grunfeld reservoir: 1 bank; 2 isobars (m)

mining; hence, the pond water level fluctuated by up to $6.6 \mathrm{~m}$, between elevation 294.1 and $300.7 \mathrm{~m}$. The "high water" mark at the pumping house wall is indicated by "a rusty surface" (Fig. 4). The influent mine wastewater contained a high concentration of sediment, which caused the silting of the reservoir and which reduced its maximum depth to $7 \mathrm{~m}$ from about $10 \mathrm{~m}$ depth prior to its mine use .

At the beginning of the 21 st century, the Gliniok reservoir ceased to be used for mine water management and as a result, the water table in the reservoir stabilised at +294.1 m above sea level (a.s.1.). The Grunfeld water table is at $293.6 \mathrm{~m}$ a.s.l. 


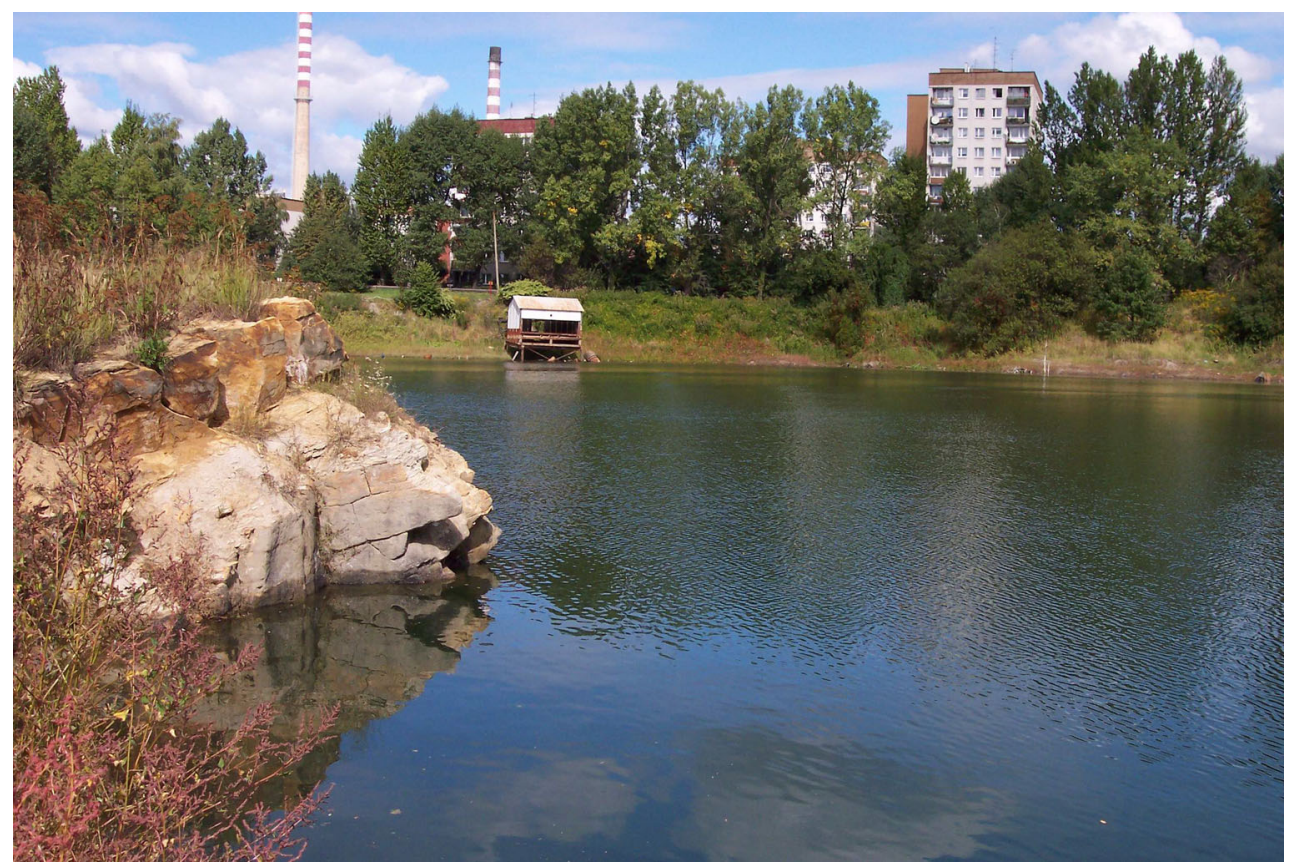

Fig. 4 Gliniok reservoir

\section{Research Methods}

Measurements of the basic physical and chemical properties of the water (temperature, $\mathrm{pH}, \mathrm{EC}$, dissolved oxygen (DO), chlorophyll (Chl), and redox potential) were done on site using a multi-parameter water quality probe (EDS 6600 , YSI Inc., USA). Before each test, the probe was calibrated using standard solutions (Hamilton Co.). The selected parameters were measured every $0.5 \mathrm{~m}$ in a vertical column located in the deepest part of the reservoir. Tests were performed in periods of mixis (spring and autumn) and stagnation (summer and winter).

Water samples were collected in polyethylene bottles for laboratory analyses at the same time as the in situ water quality measurements were taken. Samples were taken at depths representative of the surface water layer (to $0.5 \mathrm{~m}$ ) and the bottom water layer (about $0.5 \mathrm{~m}$ above the bottom). Samples of water from the surface water layer were taken using a telescopic outrigger and from the layer above the bottom using an Eijkelkamp bathometer. The water samples were transported to the laboratory at a temperature of $+4{ }^{\circ} \mathrm{C}$ and were filtered through a $0.45 \mu \mathrm{m}$ Millipore filter before analysis. Laboratory analyses were done according to Polish Standards (PN 1971-2002): chlorides were determined by titration (argentometry), and sodium ions were determined by flame photometry. Classification of hydrochemical types of water was done using the Szczukariew-Prikłoński classification (Macioszczyk 1987).

Due to non-normal distribution and unequal variance of the data, non-parametric tests were used. In order to compare differences in the medians of the selected physical-chemical

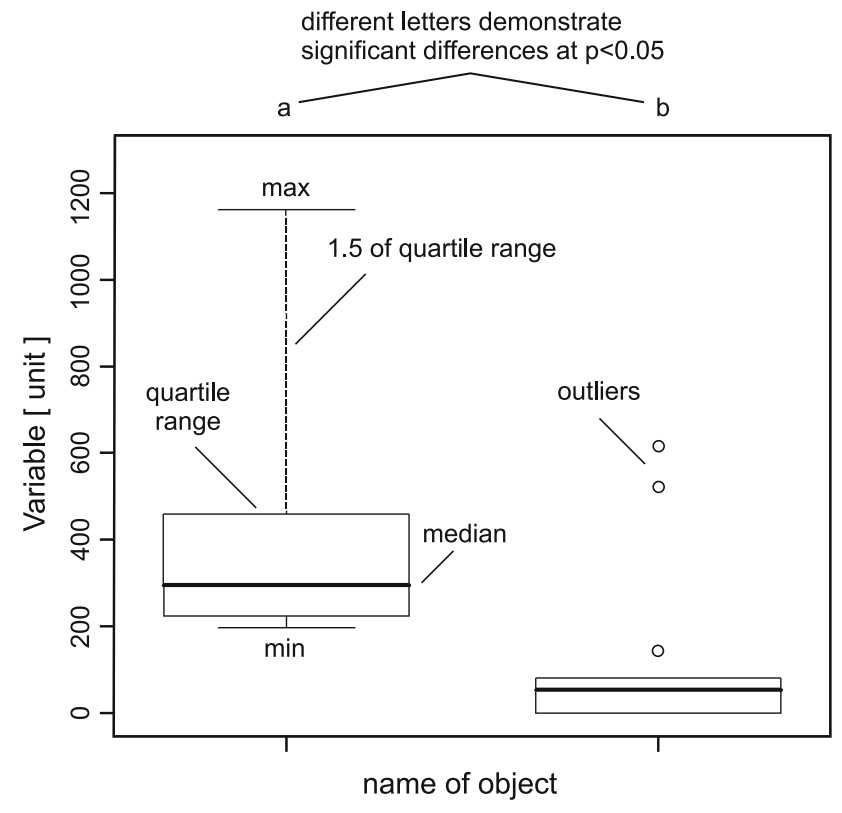

Fig. 5 Scheme of data presentation on box-whisker plots

parameters between the reservoirs studied, the ANOVA Kruskal-Wallis test was applied followed by the Conover test for multiple comparisons in case of rejection of null hypothesis. To study the relationship between the $\mathrm{pH}$ of water and its oxygenation, the Spearman rank correlation test was done. All data are presented as medians and quartile range with outliers in the figures as box-and-whiskers plots (Fig. 5). All statistical analyses in this paper were done using the $\mathrm{R}$ program (R Development Core Team 2009). 
Table 1 Means of chemical parameters of waters in studied reservoirs (surface layer, $0.5 \mathrm{~m}$ depth) in mval $\mathrm{L}^{-1}$

\begin{tabular}{lllllllll}
\hline No. & Reservoir & $\mathrm{Ca}^{2+}$ & $\mathrm{Mg}^{2+}$ & $\mathrm{Na}^{+}$ & $\mathrm{K}^{+}$ & $\mathrm{Cl}^{-}$ & $\mathrm{SO}_{4}{ }^{2-}$ & $\mathrm{HCO}_{3}^{-}$ \\
\hline 1 & Gliniok & 9.7 & 6.2 & 61 & 0.8 & 75 & 6.9 & 1.8 \\
2 & Grunfeld & 2.8 & 2.1 & 0.6 & 0.2 & 1.9 & 1.1 & 2.7 \\
\hline
\end{tabular}

\section{Results and Discussion}

The water of the Grunfeld reservoir, which is assumed to represent natural baseline conditions, is calcium-bicarbonate type $\left(\mathrm{HCO}_{3}{ }^{-}-\mathrm{Ca}^{2+}\right)$ (Table 1). Although the drainage of mining water to the Gliniok reservoir ceased in the early 2000s, the reservoir water remains a chloridesodium type $\left(\mathrm{Cl}-\mathrm{Na}^{+}\right)$(Table 1), typical of the waste water quality from many mines in the Upper Silesian Coal Basin (Różkowski 2004).

The chloride concentration in the Gliniok reservoir water is many times higher than in the water of the Grunfeld reservoir (Fig. 6). There are also differences in the Gliniok reservoir, between the chloride concentrations in the water in the surface layer compared to the bottom layer (Fig. 6). The average chloride concentration in the surface layer of water in the Gliniok reservoir was $2,044 \mathrm{mg} / \mathrm{L}$; in the bottom layer, it was $12,440 \mathrm{mg} / \mathrm{L}$. No statistically significant differences between the chloride concentrations in the surface and bottom layers of water in the Grunfeld reservoir were noted; the average concentration of chloride was $33 \mathrm{mg} / \mathrm{L}$ in the surface water and $35 \mathrm{mg} / \mathrm{L}$ in the bottom layer.

A high variability $(\mathrm{V}=46 \%)$ in the chloride concentration was observed in the water in the surface layer of the Gliniok reservoir. This is a result of the mixis processes (i.e. partial mixing of surface and deeper waters) and

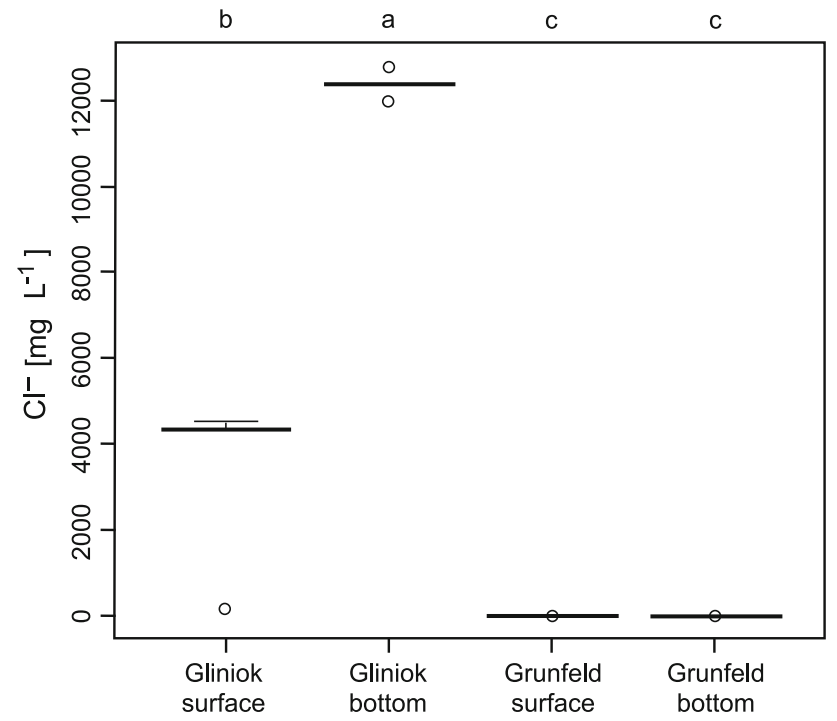

Fig. 6 Concentration of chlorides in waters of the studied reservoirs seasonal dilution from the inflow of less saline water from precipitation and ground water. The lowest chloride concentration, $350 \mathrm{mg} / \mathrm{L}$, was found after a few days of intense rainfall. Conversely, in spring and autumn (Table 2), mixis leads to incorporation of more saline water into the surface layer and thus an increase in the chloride concentration. The highest concentration of chloride, $2,700 \mathrm{mg} / \mathrm{L}$, was found during dry weather (11 days without precipitation) accompanied by strong winds $(>10 \mathrm{~m} / \mathrm{s})$. The influence of mixis and wind action is limited to the surface layers; changes in the chloride concentration in the bottom water layer (monolimnion) is many times less than at the surface $(\mathrm{V}=2 \%)$. The chloride concentrations in the monolimnion range between 14,800 and $15,000 \mathrm{mg} / \mathrm{L}$. Water with the highest mineralisation and the same density lie at the bottom of the reservoir and are minimally affected by the inflow of fresh water (thickness blockade) and wind-driven mixing.

Similar to chloride, there were significant differences in the sodium concentration between the reservoirs. There were also big differences in the Gliniok reservoir, in the concentrations of sodium in the surface and the bottom layers (Fig. 7). The average sodium concentration in the surface water layer in the Grunfeld reservoir was $12 \mathrm{mg} / \mathrm{L}$, while in the Gliniok reservoir surface water the sodium concentration was $1,517 \mathrm{mg} / \mathrm{L}$. The differences between the reservoirs and their layers are the result of the same processes previously described for chlorides.

An EC survey showed similar depth dependency in the Gliniok reservoir (Fig. 8). The EC is low in the upper 1-2 $\mathrm{m}$ (mixolimnion zone) and gradually increases (chemocline zone) with depth, becoming stable in all seasons (monimolimnion zone) at a depth of 4-7 $\mathrm{m}$ with an EC of about $35,000 \mu \mathrm{S} / \mathrm{cm}$. This type of permanent EC distribution in a vertical column of a reservoir is a characteristic of meromictic reservoirs (Dietz et al. 2012; Espana et al. 2009; Hongve 1980; Kazanci et al. 2008; Żurek 2002). A similar survey in the Grunfeld reservoir showed no major differences in the EC values in the spring and autumn mixis periods (Fig. 9). Stable water stratification in the Gliniok reservoir is due to the highly saline mine water, which has a high density compared to natural water reservoirs.

Oxygen profiles are also a reflection of a meromictic reservoir character. This parameter, along with $\mathrm{EC}$, is very often used as evidence of a meromixis phenomenon (Galas 2003; Kazanci et al. 2008). Oxygen profiles had a positive 
Table 2 Climate characteristics of Katowice

\begin{tabular}{|c|c|c|c|c|c|c|c|c|c|c|c|c|c|}
\hline Month & Jan & Feb & Mar & Apr & May & Jun & Jul & Aug & Sep & Oct & Nov & Dec & Year \\
\hline Mean air temperature $\left({ }^{\circ} \mathrm{C}\right)$ & -3.3 & -2.1 & 1.9 & 7.6 & 13.0 & 16.5 & 18.0 & 17.3 & 13.6 & 8.1 & 3.4 & -0.6 & 7.8 \\
\hline Mean precipitation $(\mathrm{mm})$ & 49 & 46 & 41 & 37 & 40 & 49 & 85 & 89 & 105 & 88 & 53 & 50 & 731 \\
\hline Mean speed of wind $(\mathrm{m} / \mathrm{s})$ & 3.0 & 2.5 & 3.0 & 4.0 & 3.5 & 3.5 & 3 & 2.5 & 3.0 & 4.0 & 4.0 & 3.0 & 3.25 \\
\hline
\end{tabular}

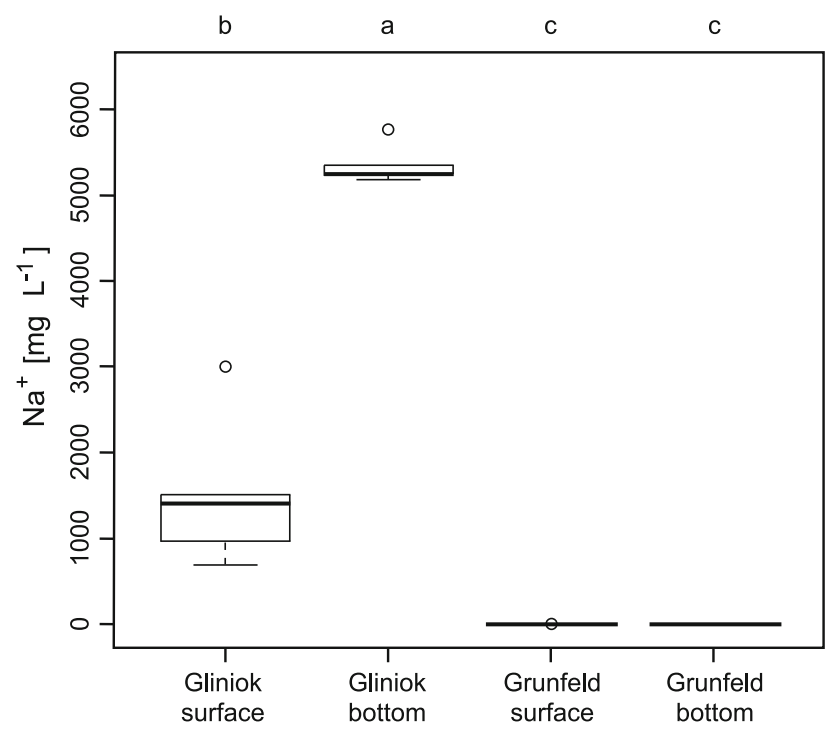

Fig. 7 Concentration of sodium in the studied reservoirs
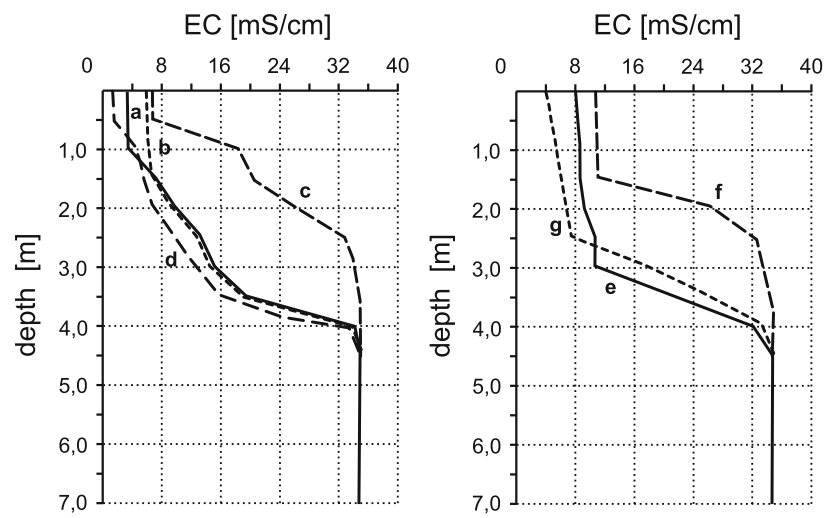

Fig. 8 Electrical conductivity (EC) profiles of the Gliniok reservoir: $a$ Autumn, 2008; $b$ Spring, 2008; $c$ Autumn, 2009; $d$ Spring, 2009; $e$ Winter, 2008; $f$ Winter, 2009; $g$ Summer, 2008

heterograde shape (Fig. 10) in all of the seasons in the Gliniok reservoir. A very high degree of saturation was observed in the chemocline, with oxygen content reaching $320 \%$ of the value at the surface. Thus, a very distinctive oxycline was measured with maximum supersaturation values in the chemocline throughout the year. This supersaturation of water with oxygen results from the photosynthesis processes, because there is a significant degree of correlation $(r=0.81)$ between this reaction and the oxygenation of water $\left(\mathrm{pH}-\mathrm{O}_{2}\right)$ (Fig. 11). Such a strong relation
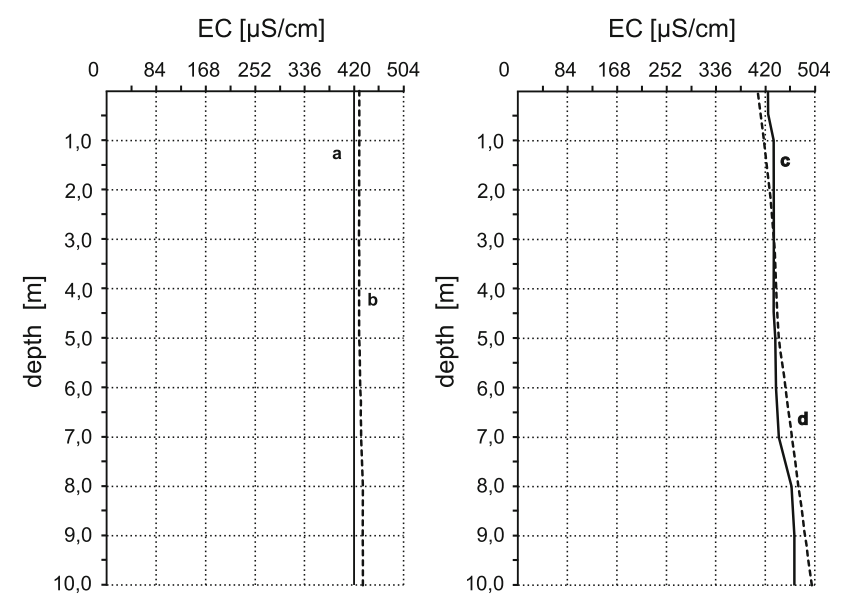

Fig. 9 Electrical conductivity (EC) profiles of the Grunfeld reservoir: $a$ Autumn, 2008; $b$ Spring, 2008; $c$ Winter, 2008; $d$ Summer, 2008
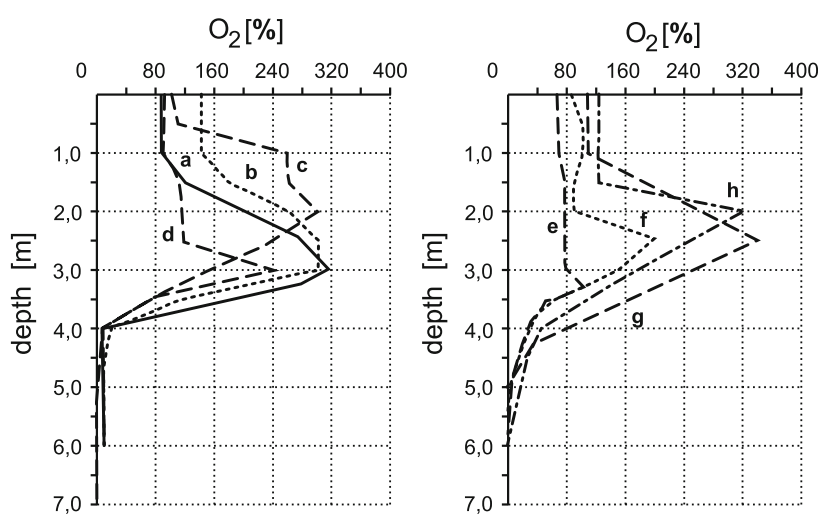

Fig. $10 \mathrm{O}_{2}$ concentration profiles in the Gliniok reservoir: $a$ Autumn, 2008; $b$ Spring, 2008; $c$ Autumn, 2009; $d$ Spring, 2009; $e$ Winter, 2008; $f$ Winter 2009; $g$ Summer, 2008; $h$ Summer, 2009

indicates intensive photosynthesis, as has been shown in similar water bodies (Neverova-Dziopak 2007). Intensive photosynthesis is the result of a high phytoplankton biomass. The average concentration of chlorophyll $a\left[\mathrm{Chl}_{a}\right]$ in the chemocline was $46 \mu \mathrm{g} / \mathrm{L}$.

There were permanent anaerobic conditions in the Gliniok reservoir monimolimnion; water samples from this layer had a strong smell of hydrogen sulphide $\left(\mathrm{H}_{2} \mathrm{~S}\right)$. The average redox potential value was- $200 \mathrm{mV}$ in the monimolimnion and oxidative conditions $(+100 \mathrm{mV})$ in the mixolimnion (Fig. 12). 


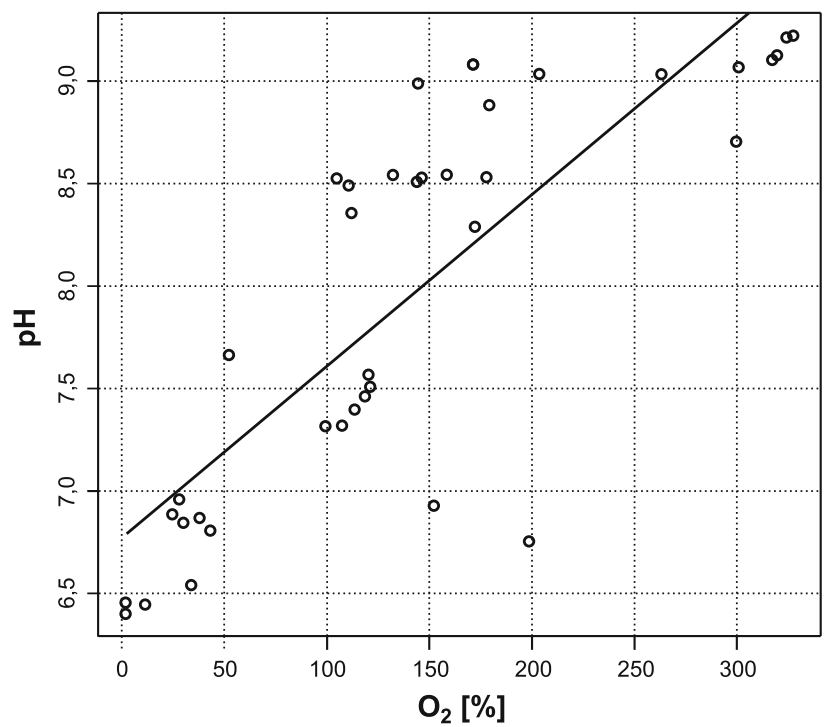

Fig. 11 Correlation between $\mathrm{pH} \mathrm{O}_{2}$ and oxygen in waters of the Gliniok reservoir

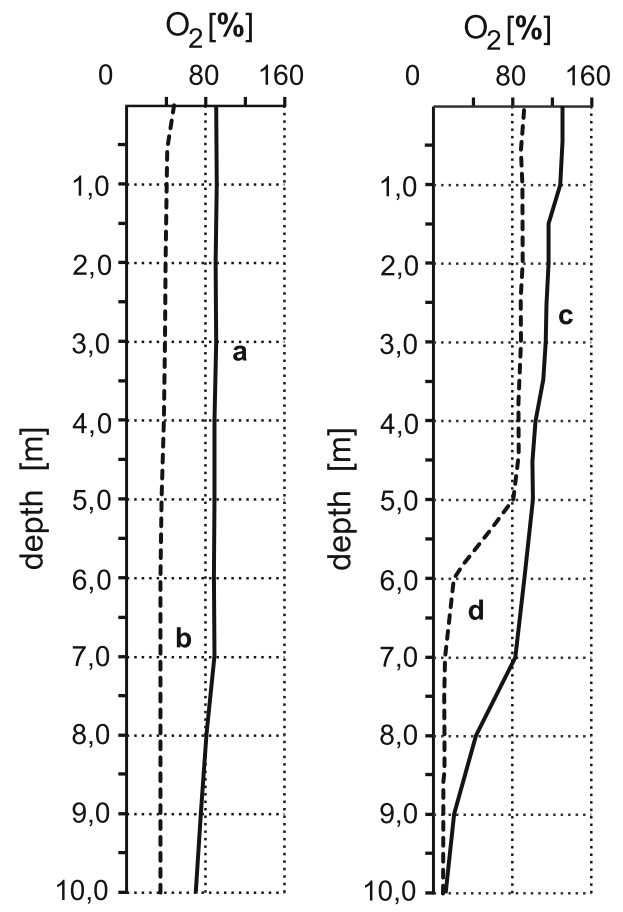

Fig. 12 ORP profiles in the Gliniok reservoir: a Autumn, 2008; $b$ Spring, 2008; $c$ Autumn, 2009; $d$ Spring, 2009

Oxygen measurements with depth in the Grunfeld reservoir had a clinograde shape during winter and summer stagnation periods (Fig. 13). During the summer, the epilimnion water was supersaturated with oxygen (up to $140 \%$ ); however, there was an oxygen deficit in the hypolimnion. Such a distribution of oxygen is characteristic of eutrophic reservoirs (Choiński 2007). Grunfeld was also found to have a lower phytoplankton biomass (average concentration of chlorophyll a in the epilimnion was $6 \mu \mathrm{g} / \mathrm{L}$ ).

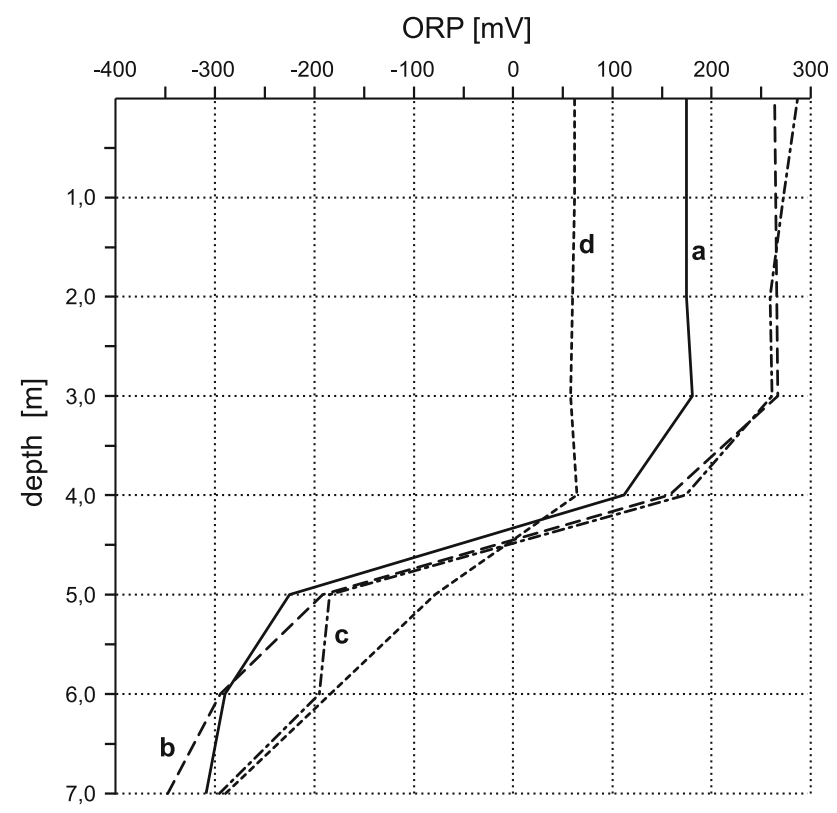

Fig. $13 \mathrm{O}_{2}$ concentration profiles in the Grunfeld reservoir: $a$ Autumn, 2008; $b$ Spring, 2008; $c$ Winter, 2008; $d$ Summer, 2008

Non-typical thermal configurations were found in the Gliniok reservoir, particularly in winter. In winter, the temperature of the bottom water should be about $4{ }^{\circ} \mathrm{C}$ (Choiński 2007; Kajak 1998). However, the temperature variation with depth in the Gliniok reservoir was reversed from the temperature depth relationship in normal lakes, with the temperature increasing with depth until reaching a maximum value of $16{ }^{\circ} \mathrm{C}$ at depth (Fig. 14). The thermal profiles versus depth also had a very distinctive temperature distribution in summer (Fig. 14); the maximum temperature in the chemocline was $32{ }^{\circ} \mathrm{C}$, which is about $3{ }^{\circ} \mathrm{C}$ higher than the maximum temperature generally recorded in lakes in Poland (Choiński 2007). Such a strong heating of chemocline waters is due to the accumulation of heat in a high EC layer and has been observed in other meromictic lakes (Hamish et al. 1970; Skowron 1995) as well as in other anthropogenic reservoirs into which saline mine water was discharged (Molenda 2011). In contrast to the Gliniok reservoir, thermal profiles in the Grunfeld reservoir had a distribution of temperature that is characteristic of normal lakes (Fig. 15).

\section{Summary and Conclusions}

The Gliniok reservoir, which in the past was used for mine wastewater disposal, is a meromictic reservoir with chemical and physical characteristics that are very different from a normal reservoir, such as the Grunfeld reservoir. In comparison, the Gliniok reservoir has a very high EC and the chemistry is dominated by chloride and sodium ions. A 
Fig. 14 Temperature profiles in the Gliniok reservoir: $a$ Autumn, 2008; $b$ Spring, 2008; c Autumn, 2009; $d$ Spring, 2009; $e$ Winter, 2008; $f$ Winter 2009; $g$ Summer, 2008; $h$ Summer, 2009

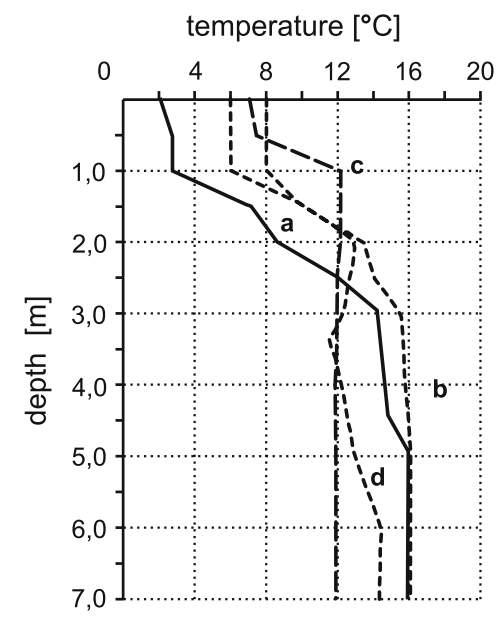

temperature $\left[{ }^{\circ} \mathrm{C}\right]$

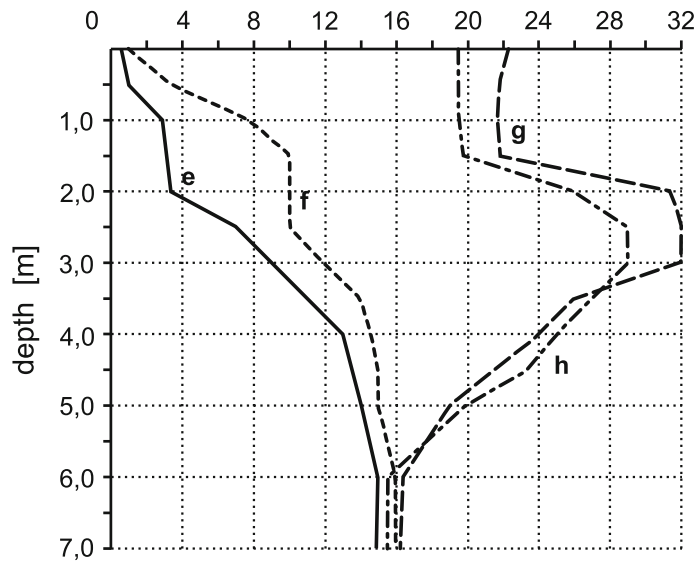

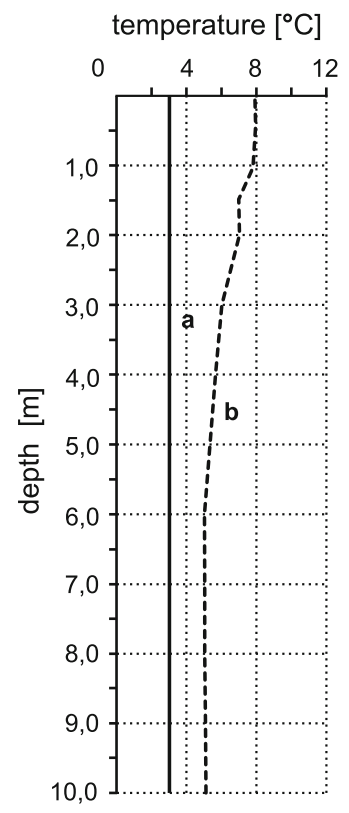

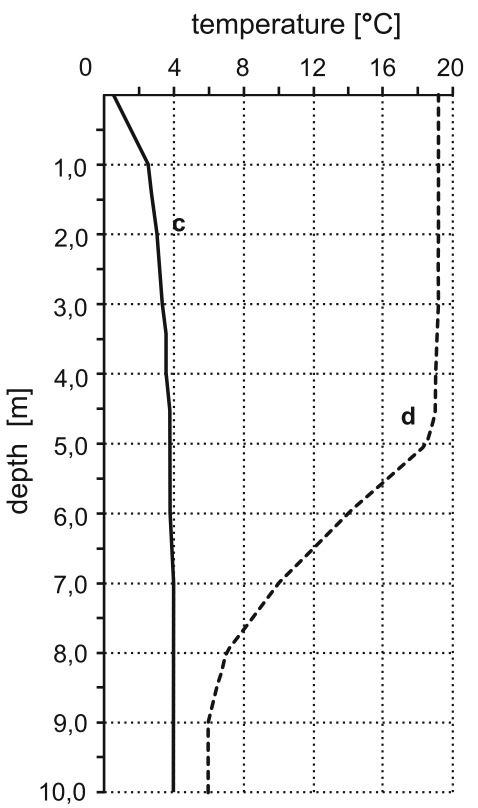

Fig. 15 Temperature profiles of the Grunfeld reservoir a Autumn, 2008; $b$ Spring, 2008; $c$ Winter, 2008; $d$ Summer, 2008

significant increase in EC was found with increased depth, and permanent stratification exists. Three zones characteristic of meromictic water bodies can be distinguished in the Gliniok reservoir: a surface atmosphere responsive zone (mixolimnion), a transition zone (chemocline), and a bottom unmixed layer (monolimnion). The surface water of the mixolimnion layer is characterised by a high variability in EC and in measured ion concentrations $\left(\mathrm{Cl}^{-}\right.$and $\left.\mathrm{Na}^{+}\right)$ compared to the stagnant monimolimnion water. The variability in the chemistry of the mixolimnion layer is the result of dilution by precipitation and the inflow of melt water. Another characteristic of the Gliniok reservoir is the high summer temperature $\left(32{ }^{\circ} \mathrm{C}\right)$ in the chemocline, which is the highest recorded for lakes in Poland. In winter, the temperature remains high $\left(16^{\circ} \mathrm{C}\right)$ in the monimolimnion. The oxygen profiles have the shape of a positive heterograde and the chemocline water shows a significant degree of oxygen supersaturation.

Acknowledgments I greatly acknowledge Ms. Michele Simmons for her linguistic assistance. Two anonymous reviewers provided valuable comments on the previous version of the paper. The study was partially supported financially by the Polish Ministry of Science and Higher Education (Grant No. N N305 2531 33).

Open Access This article is distributed under the terms of the Creative Commons Attribution License which permits any use, distribution, and reproduction in any medium, provided the original author(s) and the source are credited.

\section{References}

Boehrer B, Schultze M (2008) Stratification of lakes. Rev Geophys 46:RG2005. doi:10.1029/2006RG000210

Choiński A (2007) Limnologia fizyczna Polski. Wydawnictwo Naukowe UAM, Poznań

Czop M, Motyka J, Sracek O, Szuwarzyński M (2011) Geochemistry of the hyperalkaline Gorka pit lake in the Chrzanow Region. Southern Poland. Water Air Soil Pollut 214:423-434

Dietz S, Lessmann D, Boehrer B (2012) Contribution of solutes to density stratification in a meromictic lake (Waldsee/Germany). Mine Water Environ 31:129-137. doi:10.1007/s10230-012-0179-3

Espana JS, Pamo EL, Diez M, Samtofimia E (2009) Physico-chemical gradients and meromictic stratification in Cueva de la Mora and other acidic pit lakes of the Iberian Pyrite Belt. Mine Water Environ 28(1):15-29. doi:10.007/s10230-008-0059-z

Frankiewicz A, Pucek R (2006) Hydrogeological and hydrochemical characteristics of the partially flooded Piaseczno opencast sulphur mine in southeastern Poland. Mine Water Environ $25: 153-162$

Galas J (2003) Limnological study on a Lake Fordem in a limestone quarry (Kraków, Poland) I. Water chemistry. Pol J Environ Stud 12(3):297-300

Hamish C, Carter D, Carter J (1970) The meromixis of Sunfish Lake. Southern Ontario. J Fish Res Board Can 27(5):847-855

Hongve D (1980) Chemical stratification and stability of meromictic in the Upper Romerike district. Aquat Sci 42(2):171-195

Hutchinson GE (1957) A treatise on limnology, vol 1. Wiley, NYC 
Jędrczak A (1992) Skład chemiczny wód pojezierza antropogenicznego w Łuku Muzakowskim. Wydawnictwo Wyższej Szkoły Inżynierskiej, Zielona Góra

Kajak Z (1998) Hydrobiologia. Limnologia. Ekosystemy wód słodkich. PWN, Warszawa

Kazanci N, Muzaffer D, Sonmez G (2008) The physico-chemical and biological characteristics of Koycegiz Lake in south-western Turkey between 1991 and 1993 and future management proposals. Rev Hydrobiol 2:165-205

Macioszczyk A (1987) Hydrogeochemia. Wydawnictwa Geologiczne Warszawa, Poland

Madonia P, Naselli-Flores L, Parello F, Parlato B (2006) Geological development of a gypsum lake formed at the beginning of the 20th century in central Sicily. Italy: integration of historical data with modern survey techniques. Chem Ecol 22:S333-S347. doi: $10.1080 / 02757540600557728$

Molenda T (2005) O niektórych specyficznych właściwościach fizyczno- chemicznych wód zbiorników antropogenicznych. Lakes and artificial water reservoirs natural processes and socio-economic importance. Sonowiec, Poland

Molenda T (2011) Naturalne i antropogeniczne uwarunkowania zmian właściwości fizyczno-chemicznych wód w pogórniczych środowiskach akwatycznych. Na przykładzie regionu górnośląskiego i obszarów ościennych. Wydawnictwo Uniwersytetu Śląskiego, Katowice
Motyka J, Postawa A (2000) Influence of contaminated Vistula River water on the groundwater entering the Zakrzówek limestone quarry. Cracow region. Poland. Environ Geol 39(3/4):398-404

Neverova-Dziopak E (2007) Ekologiczne aspekty ochrony wód powierzchniowych. Oficyna Wydawnicza Politechniki Rzeszowskiej, Rzeszów

R Development Core Team (2009) R. A language and environment for statistical computing. R Foundation for Statistical Computing, Vienna

Różkowski A (2004) Środowisko hydrogeochemiczne karbonu produktywnego Górnośląskiego Zagłębia Węglowego. Wyd Uniwersytetu Śląskiego, Poland

Skowron R (1995) Dynamika temperatury wody i zasobów ciepła w meromiktycznym jeziorze strefy polarnej (NW Spitsbergen) w okresie lata polarnego. XXII Symposium Polarne, Wrocław-Książ

Wilk-Woźniak E, Żurek R (2005) Phytoplankton and its relationships with chemical parameters and zooplankton in meromictic reservoir. Aquat Ecol 40:165-176. doi:10.1007/s10452-005-0781-6

Żurek R (2002) Pecularities of a sunken sulphur strip mine (Reservoir Piaseczno, Southern Poland). Ecology and ecotechnologies. In: Proceedings, review Conference on Scientific cooperation between Austria and Poland 